\title{
Is the 2019 Water Revolution a lesson of emancipatory education? A Rancièrean invitation
}

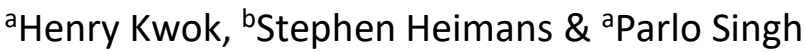

${ }^{a}$ Griffith Institute for Educational Research, Griffith University

${ }^{b}$ School of Education, the University of Queensland

Email contact: henry.kwok@griffithuni.edu.au

\begin{abstract}
This paper starts with an apparently provocative question - can we call the 2019 Water Revolution in Hong Kong a lesson of emancipatory education which awakens students' critical consciousness and brings the postcolonial regime into democratic renewal? The mass social unrest, which was initially triggered by a controversial extradition legislation, has prompted local journalism and political discourse to speak of 'the failure of education': an outmoded form of citizenship education, lack of Chinese History as a core subject, radicalisation in school, regression in science and technology education, to name just few examples of crisis talk. Our discussion explores this question through the philosophical lens of Jacques Rancière. In Rancière's understanding, 'emancipation' occurs in the ephemeral moments of subjectification in which individuals resist existing identity positions in the 'police' order, but speak on their own terms through 'dissensual' responses, under the supposition of 'equality' of 'intelligence'. Episodes of the movement may look defiant but are not the rare moments of 'dissensus' in which people are unshackled from the prevalent distribution of the sensible. An example from this movement that borders on what Rancière means by 'emancipation' is the redistribution of chemistry knowledge about tear gas on a social media platform, which is initiated and crowdfunded by a group of anonymous postgraduate science students and circulated by a chemistry tutor from a private tuition school.
\end{abstract}

Keywords - dissensus, emancipation, Rancière, Water Revolution

Politics exists wherever the count of parts and parties of society is disturbed by the inscription of a part of those who have no part. - Jacques Rancière

\section{Introduction}

At first sight, the question raised in this paper may sound rather arrogant, if not only provocative. How can one describe the tumultuous year of 2019 in Hong Kong as an educative lesson of emancipation, if it is not a history of total failure? Political leaders fail to act, activists fail to overthrow an austere regime, teachers fail to educate young, patriotic minds. Readers might take offence.

The mass social unrest in Hong Kong is no doubt an unprecedented crisis of the greatest 
magnitude that no one could have foreseen in their crystal ball. What has gone wrong in our education system? The knee-jerk reaction from conservatives is to lay blame on education for all social ills. 'This generation of black-shirt "warriors" aren't patriotic enough because they didn't study Chinese History in schools.' 'There is too much political knowledge in Liberal Studies.' 'Hong Kong teachers are too political, and they indoctrinate our children.' 'The post-2009 curriculum reform eviscerates STEM education but crams the curriculum with too much useless knowledge.' 'Our universities shoehorn too many students into a saturated job market, which provides very few opportunities for local graduates.' Those who have been swimming in the language of progressivism speak of failure too. 'Hong Kong does not have enough political education.' 'Hong Kong school curriculum needs to be more political.' 'Teachers need to stand up against the police state.' 'The austere regime is eroding school autonomy, and now it's time to fight.'

Any discourse of crisis is an assertion of particular narratives, assumes certain values and privileges particular questions (Clarke, 2019). Progressive views and conservative narratives might sound contradictory, but upon a closer look into the crisis discourse, they share the same logic that has been perplexing educators since time immemorial. How could education contribute to human freedom, and 'emancipate' students from ignorance (Biesta, 2013)? It is the keyword 'emancipation', which has stirred up so much political passion, that draws our attention to the corpus of the French philosopher Jacques Rancière.

Rancière wrote extensively on diverse topics ranging over cinema, aesthetics, education, literature, politics, history and democracy. His work does not sit narrowly in one clearly defined genre. Sometimes, his writings straddle a historical account and a philosophical treatise. Some writings offer an exegesis of classics and distil a philosophical response to contemporary issues. His work does not provide a neat 'theory' that poses as an orthodox doctrine or formula to be 'applied' or 'practised' in classrooms. In this paper, we treat his philosophy as resources or, in his word, an 'intervention'. An 'intervention' compels us to ask, retrospectively:

where are we now?...how can we characterise the situation in which we live, think and act today?...how does the perception of this situation oblige us to reconsider the framework we use to 'see' things and map situations, to move within this framework or get away from it?...how does it urge us to change our very way of determining the coordinates of the 'here and now'?

(Rancière, 2009, pp. 114-115)

This paper is an invitation that prompts us to 'reconsider the framework we use to "see" things and map situations', in the light of the provocative present in Hong Kong. Is the political upheaval in Hong Kong an emancipatory lesson for students? We invite the work of Rancière to speak to us, and 'explore' this question, but refuse hurrying towards a premature answer. Rancière's philosophy is not a readymade solution that comforts our troubled souls after the feverish year of 2019. His approach is a rupture - a theoretical break that agitates the way we talk and think and define problems and vocabulary that have been thrust upon us. Specifically, we argue that 'emancipation' only occurs in the 
fleeting moment of 'subjectification', when individuals resist the existing identity positions but speak on their own terms, under the supposition of equality of intelligence. The ephemeral moment of emancipation occurs not in the 'police' order that divides the community and individuals into different roles, groups and functions, but it is a 'political' moment that interrupts this order, supplementing it with those who have no part. One example that comes close to this Rancièrean notion of 'emancipation' is the self-initiated experimental study of chemistry knowledge conducted and crowdfunded by a group of anonymous postgraduate science students, which is related to the toxic remnants of tear gas fired by the riot in the community, and is redistributed by a chemistry teacher from a private tutorial school on the Internet.

\section{Do students need to be 'emancipated'?}

More fundamentally, do students need to be 'emancipated'? The ambition to 'emancipate' students has always been on the mind of educators. It invokes great fear, even before the uprising broke out in June. We dread over the idea that students, who might be conceived as tabula rasa, are drunk in the potent drug called 'politics' - either the nationalistic prescription from the Mainland or the overdose of democratic extremism from the political opposition. In whatever wavelength of political spectrum, this discourse to 'emancipate' students from ignorance to freedom and intelligence is all too clear. To the former Permanent Secretary for Education, the younger generation have been exposed to too much 'fake news' in social media and thus are deprived of the capacity for critical and independent thinking ${ }^{1}$. On the other side, in the eyes of millennials who clamour for greater democratisation, all baby-boomers were simply a group of ignorant people who are completely illiterate in politics but are only obsessed with economic development, growth and social stability, at the expense of the future generation and social justice. It is, therefore, their task to educate the older generation.

As Deleuze (2015) said, the use of political concepts (such as 'democracy', 'politics', 'the rule of law', 'human rights', 'critical thinking', 'independent thinking' etc.) 'brought to light the very contradictions in which the patient has become entangled.' (2015, p. 10) Whether one has a formal study of politics or not, we all latch onto these concepts on our lips. It is not that we know or own these concepts. In Deleuze and Guattari $(1994,2016)$ terms, we are 'immanent' to them. We enter into this plane of immanence where ideological positions are divided into the categories of 'yellow ribbon' millennials who clamour for more political rights, and a stubborn generation of 'blue ribbon' babyboomers who hog the way for constitutional reform. Both sides, regardless of our contradictions and political hue, want to 'emancipate' each other, with our own pedagogy.

Isn't 'emancipation' a conspicuous agenda obscured in this movement, as already told clearly in the revolutionary slogan 'reclaiming Hong Kong, revolution of our times'? The challenge of this pithy expression does not lie in the contested term 'revolution', which, for so many sleepless nights, has annoyed the paranoid Communists in Peking. (It makes sense for the leaders to worry as they grew their political power out of a gun barrel.) The contested word remains somewhere. As Zhang Xiaoming, the former Director of the 
Liaison Office in Hong Kong once commented: what does the movement 'reclaim' in Hong Kong, and to where?

\section{Modern logic of emancipation and its problems}

Zhang's comments are of course an affront to the 'martyrs' or 'warriors', in the eyes of a lot of pro-democracy supporters who vehemently decry dictatorship and police brutality. His views, however, have some grain of truth in the sense of a critique against the Enlightenment tradition on 'emancipation'. The loaded verb 'reclaiming' is right at the heart of Rancière's comments on the modern logic of 'emancipation' bequeathed to the present since Kant. The modern conception of 'emancipation', writes Biesta (2013) in his reading of Rancière's The Ignorant Schoolmaster (1991), veils three contradictions: the logic of dependency, an unequal relation between the emancipator and the emancipated, and the fundamental distrust and suspicion of the experiences of the emancipated. In the educational context, the colonial logic of dependency assumes that students solely depend upon a teacher for escaping from ignorance. But as Rancière argues, the moment 'where one searches for the hidden beneath the apparent, a position of mastery is established' (2011a, p. 49). This in turn creates a relation of inequality between the teacher and the students as the logic assumes that the emancipated one depends upon the 'truth' or 'knowledge' from the more powerful and knowledgeable emancipator. 'To explain something to someone is first of all to show him he cannot understand it by himself.' (Rancière, 1991, p. 6) Whether it is in the account of Kant or Freire, the modern logic of 'emancipation' assumes the experiences of the emancipated is not reliable but only a master teacher and an emancipator has the sole authority to judge whether one is free and knowledgeable. Any pedagogical practices based on this colonial logic never lead to emancipation, but only 'enforced stultification' (Rancière, 1991, p. 7).

Here, we do not want to deliver a hasty judgement on whether the discourse about the younger generation, from both sides of the political scene, exhibits such a modern logic of 'emancipation' during the 2019 movement. But the intention to pedagogise people into this modern conception of 'emancipation' has always been present in public discourse, which is never tired of giving out pedagogic discourse:

...there were all kinds of men of goodwill who were preoccupied with instructing the people: rulers wanted to elevate the people above their brutal appetites, revolutionaries wanted to lead them to the consciousness of their rights; progressives wished to narrow, through instruction, the gap between the classes; industrialists dreamed of giving, through instruction, the most intelligent among the people the means of social promotion. All these good intentions came up against an obstacle: the common man had very little time and even less money to devote to acquiring this instruction.

(Rancière, 1991, p. 17)

Whether a curriculum is too 'radical' or too 'nationalistic' is beside the point. What Rancière's work stimulates us to think about is the problem of 'enforced stultification' obscured behind the modern logic of 'emancipation' in all political agenda, i.e., students cannot exercise their own intelligence and learn about things on their own, but solely 
need to depend upon a master explicator who provides explication as a way of learning. All educational responses to the movement, whether it is from the pro-government side pressing for a stronger boost of nationalism or from the political opposition advocating for including more progressive elements into the existing curriculum, carry the potential for 'enforced stultification'.

\section{The 'enforced' stultification of the 'police' order}

'Enforced stultification' can happen anywhere, no matter which ideological position one is identifying himself/herself with. Any educational or policy discourse that promises 'emancipation', though romantic or progressive it sounds, does not automatically lead to learning. 'There is stultification whenever one intelligence is subordinated to another.' (Rancière, 1991, p. 13) If teachers solely believe in explanation without noticing how children use their own intelligence, it is no different from creating a partition of the world, i.e., 'a world divided into knowing minds and ignorant ones, ripe minds and immature ones, the capable and the incapable, the intelligent and the stupid' (Rancière, 1991, p. 6). If anyone believes that the world is only divided into 'yellow ribbons' or 'blue ribbons' or a politically intelligent and a politically illiterate mind, such pedagogy is not far from stultification, but not yet emancipation.

People on the streets, whether they feel that they have a part or not, undoubtedly, talk more about politics after the 2014 and 2019 political crises. There is a heightened sense of political awareness but it is by no means equivalent to what Rancière defines as 'emancipation'. There are all sorts of labels tagged for a person's political beliefs. 'This person is a "radical"'. 'That person is "a yellow ribbon"'. 'His view is "moderate".' 'There is no neutral position but only "yellow" and "blue".' In Rancière's words, such gestures of pigeonholing individuals into a pre-existing ideological tribe are merely 'identification', i.e., taking up an existing identity, an existing way of being and speaking that has already be made possible in the 'perceptual field' or 'sensible world' (Rancière, 2003, p. 226). The perceptual field is not only the binary logic of 'black-and-white'; now the dualism is 'yellow' and 'blue'.

'Identification' belongs to the existing order called the 'police' order, i.e., 'the law, generally implicit, that defines a party's share or lack of it. But to define this, you first must define the configuration of the perceptible in which one or the other is inscribed.' (Rancière, 1999, p. 29) In Rancière's vocabulary, 'police' or 'police order' (in French, La Police or L'Ordre policier) does not just refer to the low-level police force as a law enforcement agency (in French, he uses la basse police to suggest this sense). The 'police' is 'an order of bodies that defines the allocation of ways of doing, ways of being, and ways of seeing'... 'an order of the visible and the sayable that sees that a particular activity is visible and another is not, that this speech is understood as discourse and another as noise.' (Rancière, 1999, p. 29)

Rancière's distinction between the 'police' order and real 'politics' is instructive. The everyday action that we consider as 'political' is not necessarily 'emancipatory', nor will it lead to human freedom, but is stuck in the quagmire of the 'police' order that results in 
'enforced stultification'. Even the pattern of social movement in Hong Kong can give us a glimpse into how this 'police' order works. The sensible fault line has always been distributed to us: this group is 'the pan-democracy camp', that person is a panda-hugger who is servile towards the Chinese, the Civil Human Rights Front liaised with the Hong Kong police to ensure the annual 1st July mass protest went smoothly, in an orderly fashion. The familiar 'Be Water' directive is also an order that allocates and defines ways of protesting, despite the apparent disappearance of central command from civil society groups. The emergent plea for a 'united front' amongst the pro-democracy sympathisers also implies the existence of a perceptible order. The 'moderates' (the majority of whom follow the principle of civil disobedience and peaceful, non-violent protests) should tolerate the 'warriors' (those minority groups who are clad in black shirts, facemasks and are willing to adopt more radical means to confront the riot police) and both forces should come together against the brutal regime. The immediate and uncomfortable question is - who is the symbolic regulator of consciousness that distributes such a perceptible division? And for whom?

Our reading of this movement, unfortunately to the chagrin of progressive enthusiasts, is that the desperate, anxious appeal for spiritual unity or social division of protest labour regardless of civil or military tactics does not amount to a genuine 'political' moment of 'emancipation', but only a stultification of a 'police' order, 'an order of body' that still allocates 'ways of doing, ways of being, and ways of seeing' - or more accurately, 'ways of protesting and supporting a mass movement'. The symbolic regulator of consciousness who circulates the slogan 'brothers [sic] climb up the mountain, each to his own' merely parrots a pedagogy of the 'police' order. The 'warriors' and the riot police, though masked, are visible through online live broadcast in the news, mediated by technological tools such as Telegram and the online multi-category forum LIHKG. When the unrest escalated at the later stage of the movement in 2019 , on LIHKG, there started to be a call for occupying the universities - through laying bricks in the campus, building walls, blocking roads, etc. Isn't it the emergence of another 'police' order that totally departs from the 'Be Water' imperative at the beginning?

The challenge to 'enforced stultification' is: do people, those who do not have part in this 'police' order, have the opportunity to pause for a while and refuse this general law or principle that readily slots people and things into various coordinates in the landscape of social activism? Some actions in the educational scene look defiant but are in no way 'emancipatory'. Even during the movement in which students engaged in various rebellious actions in schools such as forming human chains with their neighbouring schools, setting up 'Lennon Walls' display and staging class boycott, there is a behind-thescene coordination by the teachers, who communicated with colleagues from neighbouring schools to ensure safety of the students, gave order on where the Lennon Wall display could be put up in order to avoid parents' attention, and what kinds of expressions were allowed in the post-it notes, and allowed the class boycott to take place within school premises only. 
Then, what is the real moment of 'emancipation'? Is there any educative lesson in this sixmonth-long political struggle that is truly 'emancipatory'?

\section{Subjectification: the ephemeral moment of 'emancipation'}

In Rancière's understanding, a genuine moment of 'emancipation' happens in the events of 'subjectification', that is, 'the production through a series of actions of a body and a capacity for enunciation not previously identifiable within a given field of experience, whose identification is thus part of the reconfiguration of the field of experience' (1999, p. 35). If education is an emancipatory moment that refuses 'enforced stultification', its interest should then lie in the subjectivity, or 'subject-ness' of those we educate. Emancipation is not the radicalism of throwing Molotov cocktails or having one or two regulated class boycotts with teachers' approval. Emancipation also comes with freedom, and the responsibility that comes with such freedom (Biesta, 2013, p. 4).

Unlike 'identification', a moment of 'subjectification' is 'disidentification' or 'removal from the naturalness of a place' (Rancière, 1995, p. 36). It is rare and only happens in the ephemeral moment in 'politics', not in the 'police' order. The essence of true 'politics' resides not in acts of 'identification', which only create 'noise', but in acts that disturb the 'distribution of the sensible'. It is a mode of expression that upsets 'the perceptible divisions of the police order', 'that of a part of those who have no part' (Rancière, 1999, p. 30). A genuinely 'political' moment is rare. A liberal democracy with a representative government returned by universal suffrage does not promise an absolute perturbing of the totalising 'police' order in which 'a part of those who have no part' is heard. 'Politics' itself, in Rancière's words, is 'the setting-up', 'the sphere of activity of a common that can only ever be contentious' (1999, p. 14). The result of 'subjectification' is not to reach a 'consensus' agreed by every speaking being. The operator of 'politics' is 'dissensus'. 'Dissensus' 'is not a conflict of interests, opinions, or values' but 'a division put in the "common sense"', 'a dispute about what is given, about the frame within which we see something as given.' (Rancière, 2004, p. 304). In the process of 'subjectification', an interval is open up for 'staging such scenes of dissensus' (Rancière, 2004, p. 304).

Why is the 'police' order interrupted under this process of 'emancipation'? To Rancière, it is interrupted in the name of 'equality'. Rancière does not define the concept of 'equality' as redistributing economic outcomes. The act of 'subjectification' challenges the 'natural order of bodies' in the name of 'equality' as a principle, and the process of 'emancipation' is constituted by the polemical verification of this 'equality' (Rancière, 2011a, p. 89). If a teaching process is genuinely 'emancipatory', then the following principle is of utmost importance, i.e., 'all men [sic] have equal intelligence' (Rancière, 1991, p. 18). In The Ignorant Schoolmaster, Rancière's conception of 'equality' and 'intelligence' is often misunderstood. By saying everyone has equal intelligence, Rancière does not naively claim that everyone has the same level of grey matter in their cerebral structures regardless of their age, gender, social class, cultural background and so forth. As he said, 'our problem isn't proving that all intelligence is equal. It's seeing what can be done under that supposition' (Rancière, 1991, p. 46) 'Equality is not given, nor is it claimed; it is practiced, it is verified.' (Rancière, 1991, p. 137) The keyword is 'to verify', that is, if 
any instruction is conducted under the principle that everyone has equal intelligence, and all practices follow by verifying this principle, what kinds of differences to the learners could be made.

Therefore, chanting all political slogans on our lips is not necessarily equivalent to 'subjectification'. But if a pedagogic action that 'intervenes in and reconfigures the existing order of things' (Rancière, 2004, p. 85) or identity positions, it may come close to what Rancière means as a truly 'emancipatory' moment. So, now, the question is - does the Water Revolution have any 'political' moment which ruptures the existing order of things and come close to what Rancière calls 'subjectification'?

\section{A self-initiated experimental study on dioxins in tear gas}

During the peak of the political crisis last year, there were grave concerns over the toxicity of tear gas fired profusely by the riot police, and the deleterious health effects upon the community. Thus far, there have been very little knowledge about the chemical compounds formed after the tear gas decomposed into the air under high heating temperature, and the risks to human health. Some speculate that the CS gas transformed into cyanide. The Hong Kong governments did not disclose the chemical compositions of the chemical weapon, especially the one imported from the Mainland after the United States banned exporting weapons to the Hong Kong Police Force. Neither the Health Department nor the Hong Kong Police Force released concrete scientific evidence to suggest that the tear gas cannisters, whether they were imported from the Chinese Mainland or from the United States, pose no health risks to individuals and the community. ${ }^{2}$ One rumour that stands out amongst others is that after the riot police fired tear gas, dioxins and dioxin-like compounds (DLCs), which are highly toxic and damaging to the environment, will be produced. One news reporter was diagnosed with chloracne, an acne-like eruption of blackheads, cysts, and pustules that is believed to be associated with his over-exposure to tear gas in the protest sites. A 'dissensual' aspect here is not that the public and the government clash with each other due to 'a conflict of interests, opinions, or values' only, but 'a division put in the "common sense"', a dispute about what is given by the authorities in relation to the toxic effects of the chemical weapons. It is, therefore, a matter of public interest for the authority to release relevant data. An experiment that determines the components of the remnants of tear gas is much needed.

In the everyday 'police' order, such experiments were expected to be conducted by toxicologists in the university or government laboratories. If scientists want to carry out this experiment at the university, they will write a grant proposal to the faculty or any grant-holding body (such as the Research Grants Council under the University Grants Committee in Hong Kong). Relevant government departments and producers of the CS gas cannisters may also submit the samples to a laboratory for testing. The regular order of things is that each person and each part has a role in the community according to the system of coordinates defining the distribution of the sensible - i.e., a scientist at the university tests the chemical compositions of tear gas remnants, producers of chemical weapons produce the tear gas cannisters, authorities explain to the public about the health risks posed by the chemical weapons. Ordinary citizens just learn about chemistry 
in chemistry lessons, we use Facebook or Instagram for posting news that is of their interests, and 'star' tutors from private educational business aim at profit making by providing after-school classes to students and develop their own social media pages for marketing their businesses. This is the 'police' order, the general principle that determines the distribution of the sensible and demarcates what is sayable and unsayable.

In the light of the health risks of CS gas, this 'police' order comes close to having a rupture of 'politics'. On the 18th November 2019, one social group on Facebook called the HKGETV $^{3}$ released a five-page laboratory report, which is widely circulated on the multicategory online forum LIHKG and by a famous chemistry tutor from a 'cram' school. ${ }^{4}$ The cram school tutor, who holds a chemistry doctorate, even once challenged the Health Bureau chief over the government insistence that the use of police tear gas pose no immediate health threat to the public. The study was financed through online crowdfunding. Overseas scholars were involved. The experiment involved the Department of Environmental and Occupational Health in National Cheng Kung University in Taiwan. The HKGETV is merely an online platform that facilitates the communicative and financing process. The research team did not have a lot of laboratory equipment. But through the review of their literature, they concluded that every combustion of organic substances, which include tear gas, can produce dioxins. The team from the HKGETV, which is made up of postgraduate students from the science discipline, also suggest, based on the academic advice from the Taiwanese university, that three types of experiment to collect air sample in the protest scenes are needed. The results of the laboratory analysis show that, contrary to what the authority claimed, 'every combustion of the organic substances, including tear gas...has the chance to produce traceable amount of dioxins' (HKGETV, 2019b, p. 4). Also, the same study reveals a high concentration of cyanide residue of the tear smoke canister manufactured in China, although, surprisingly, no CS was found in the Chinese-made grenade (HKGETV, 2019a, p. $6)$.

To a lot of people, distributing news on social media such as Facebook or the Internet is just a mundane, ordinary activity. A chemistry tutor from a private tutorial school uses Facebook or other social media sites as a useful platform to market his business. A science student pursuing his doctoral or master's degrees is assumed to work in their laboratory at the university. A social media site such as HKGETV is supposed to produce news, but does not serve as a website that redistributes knowledge of chemistry. However, this small-scale laboratory study is meaningful in terms of 'emancipation', i.e., suddenly, people get out of their 'proper', pre-defined places, 'repartitioning the political from the non-political' (Rancière, 2011b, p. 4). More precisely, this action is 're-partitioning the political from the chemical'.

If there is an educative lesson of 'emancipation', perhaps the emergence of this report comes very close to it. A truly 'political', 'emancipatory' moment is always 'out of place' (ibid.). A chemistry tutor from the tutorial school is circulating on his social page, not his usual advice on how to 'ace' in public exams, but a matter of concern to public health, through his expertise. The pedagogy is no longer limited to the 'police' order of public 
examinations. It is a public pedagogy that addresses matters of concern. The analysis of tear gas is not given by an academic in the university laboratory, not financed by a faculty, but is facilitated by a social media group which does not even have a postal address. In the 'police' order, those who did not study chemistry in secondary school 'have no part' but are restricted only to very few people with expensive equipment. But the circulation of the report, via the chemistry tutor or others, is a gesture inscribing 'a part of those who have no part' (Rancière, 1999, p. 123). The whole set-up, through online circulation of the report that is accessible to all with the Internet, presupposes that all readers of the report have equal intelligence to understand it and refute what the senior government officials said. Not all readers can understand chemistry, English, but the effort of the tutor explaining in Cantonese on YouTube and the summary and translation of the HKGETV team all embody the principle of 'equality'. 'One could learn by oneself and without a master explicator when one wanted to' (Rancière, 1991, p. 12). It is all up to readers to decide whether they want to learn about dioxins from the report, but the publication of the report itself assumes they can know about chemistry, without explication. I can circulate the report to others and warn others about the danger of inhaling the air, even though I am an ignorant outsider in chemistry. The redistributed laboratory report does not dictate which ideological platform people should subscribe to, but it demands a question that pretty much summarises Rancière's approach: what do you think of it? 'One can teach what one doesn't know' (Rancière, 1991, p. 31).

Rancière never means teachers and teaching have no role. 'A person - and a child in particular - may need a master when his own will is not strong enough to set him on track and keep him there. But that subjection is purely one of will over will.' (Rancière, 1991, p. 13) Whether one is teaching about socio-political participation in a Liberal Studies lesson, chemistry, or the Chinese culture in a Chinese History lesson, a teacher is necessary. But he/she is not the only master explicator. Students still need a master, especially when their own will or ability to discern is not strong enough to keep them away from distractions or 'fake' news. However, such a teaching process should be underpinned by a belief - a subjection that is 'purely one of will over will'. To Rancière, equality of intelligence is the critical ingredient for emancipation.

\section{An emancipatory lesson? or, 'everything is in everything'}

A Rancièrean approach is not merely a utilitarian imposition that taps into the learning skills' or 'human intelligence' and transferring them from the streets to the classrooms and formal curriculum. The discussion redistributes the sensible way to perceive issues, raise questions and rethink the existing framework into which we have always been dwelling. Through this act, we work towards an emergent, deeper understanding of what it means to have a lesson of 'emancipatory education' from this movement.

Rancière himself does not 'intervene' in the sense of dictating what is thinkable and unthinkable. The current discussion is not another obsolete analysis of geopolitics and global crisis of education today. It is an exercise of our using Rancière's work, and pay attention to how the rethinking of concepts opens a new vista for considering the 
emancipatory potential of the 'here and now'. Every generation of policymakers are perennially obsessed with the question of 'what's wrong with education?'. This intervention from Rancière's philosophy merely re-stages, through the everyday, ordinary moments (such as the sharing of a particular scientific report on CS gas on Facebook), the 'emancipatory' potential that passes us unnoticed in our mundane 'police' order. Rancière's work sensitises us towards the mundane moments, and explore how these disruptive moments of 'politics' speak back to the daily teaching and learning in the 'police' order of school curriculum and classroom pedagogy. It is not that political knowledge is too difficult or controversial and thus should be chucked out of school curriculum. The contemplation prompted by the Rancière's lesson is - do we believe that students all have the equal intelligence to understand such challenging, contested knowledge? Does our pedagogic practice verify this belief in equality? If we abide by this pedagogic belief, what kinds of difference can be made? The small action of doing a laboratory analysis of CS gas and its gaseous composition is not in itself a colossal scientific discovery or political revolution with a big, capital $\mathrm{R}$. The significance of this small act lies somewhere - it is redistributed with the assumption that those without advanced knowledge of chemistry, toxicology and weapon production can have the equal intelligence to understand the potential health threat from the toxic gas towards human bodies, the community and the environment. It is a 'dissensual' response reacting towards what is given - i.e., the claim from the government that the firing of tear gas does not produce dioxins. One can teach this to neighbours, friends, family members, and others, even though we have only few experts in chemistry. It is not a contrived lesson of STEM education on the lips of policymakers. The lesson of the Water Revolution perhaps is not so much about how the existing 'police' order of school curriculum should be reformed, or how we should treat the tumultuous world as a classroom. The world is not a classroom for people to manoeuvre based on our whimsical ideas, but just like the example of the self-initiated laboratory study on tear gas, 'everything is in everything'. The lesson, perhaps, is that in front of the vast body of difficult knowledge, unknowns and 'matters of concern', not too many revolutionary choices are laid in front of us, but we can only plead ignorant.

In late August, before the new academic year started, the Education Bureau (EDB) once circulated a guideline. It reads, in the midst of political crisis, when prompted by students asking questions in relation to the street violence and political events, teachers are allowed to say, 'I don't know; I don't understand either' (EDB, 2019, p. 2). This circular did infuriate a lot of people, as we all expect teachers should be the ones who can always provide an answer under the aegis of 'teacher professionalism'. But if Rancière's work is read more carefully, perhaps this guideline is actually a good start. It is not enough. Perhaps teachers should also pursue some follow-up questions: 'what do you see? What do you think about it? What do you make of it?' (Rancière, 1991, p. 23)

Perhaps, this is the 'emancipatory lesson' of the Water Revolution. 


\section{Notes}

1. Fanny Law, the former permanent secretary for education, in a radio interview, said that some young girls offered free sex to frontline protesters, even though her comment is ridiculed as 'fake news' without 'fact checking'. 'I think we have confirmed that this is a true case. I am so sad for these young girls who have been misled into offering free sex. ...There is evidence. That is the daughter of a friend's friend. That's second-hand knowledge, but it's direct, it's real. Okay? Direct and it's real. And the girl actually wrote a piece.' (Chiverton \& Rowse, 2019)

2. Sophia Chan, the Secretary for Food and Health told the Legislative Council that 'we have conducted internal studies on whether tear gas will produce dioxin or cyanide. We found no evidence based on existing research and academic literature that tear gas will generate dioxin.' (Hong Kong Free Press, 2019)

3. The name is suspected to be made up of two codes, HKG and ETV. HKG is the IATA station code of the Hong Kong International Airport. ETV stands for Educational Television (Hong Kong), which began in 1972 and is a series of educational television programmes jointly produced by Radio Television Hong Kong (RTHK) and the now erstwhile Education Department (EDB). The name of this civil society group on Facebook partly suggests a sense of nostalgia for the past in the 1990s when ETV was known to be part of the collective memory of the city's colonial past.

4. Known as the 'godfather of chemistry' among secondary school students, Dr K. Kwong is a well-known chemistry tutor from a private tutorial chain called Modern Education. His teaching notes are widely known to be very relevant to students for their public examinations. During the movement, he made several comments on the Hong Kong government's method of handling the protest and tear gas.

\section{Disclosure statement}

No potential conflict of interest was reported by author(s).

\section{Notes on contributors}

Mr Henry Kwok is a PhD candidate in the Griffith Institute for Educational Research at Griffith University, Australia.

He is former a Senior Lecturer in Sociology of Education at the Open University of Hong Kong. He graduated from

the University of Hong Kong and the University of Cambridge. His research interests include critical policy studies,

the politics of curriculum and education reform, and the use of social theory in educational research. 
Dr Stephen Heimans is a Senior Lecturer in Educational Leadership at the University of Queensland, Australia, and an adjunct Senior Research Fellow at the Griffith Institute for Educational Research, Griffith University. His work focuses on the relations between the purposes, policies and practices of education, participatory design-based research and social justice.

Prof Parlo Singh is a Research Professor and Senior Academic Fellow at Griffith University, Australia. Her research work focuses on issues of educational equity and social justice. Specifically, she is interested in research partnership work that assists students from disadvantaged communities to gain access to complex forms of knowledge. Of particular significance is work that challenges the re-production of social inequity via schooling systems through complex sociological theorising.

\section{References}

Biesta, G. (2013). The Beautiful Risk of Education. Routledge.

Chiverton, H., \& Rowse, M. (2019 September 9). Young girls offering sex to protesters: Fanny Law. In Backchat. RTHK Radio https://news.rthk.hk/rthk/en/component/k2/1479601-20190909.htm

Clarke, M. (2019). Lacan and education policy. Bloomsbury Academic.

Deleuze, G. (2015). Preface: Three group-related problems. In A. Hodges (Trans.), Psychoanalysis and Transversality: Texts and Interviews 1955-1971 (pp. 7-21). MIT Press.

Deleuze, G., \& Guattari, F. (1994). What is philosophy? (H. Tomlinson \& G. Burchell Trans.). Verso.

Deleuze, G., \& Guattari, F. (2016). Anti-Oedipus (R. Hurley, M. Seem, \& H. R. Lane Trans.). Bloomsbury Academic.

Education Bureau (EDB). (2019). Caring the Emotions of Teachers and Students. Education Bureau.

HKGETV (2019a). The Analysis of Tear Gas in Hong Kong - 1st Investigation of the 2Chlorobenzalmalononitrile (CS) Residue Content Inside the Tear Gas Canister from Different

Manufacturers. https://cdn.hkgetv.com/report/HKGETV\%20Tear\%20Gas\%20Project\%20Report\%20(Cani sters).\%2020191128.pdf?fbclid=IwAR3IKhy6FOpC3Gsq 42s9omcDBTvFyF4B3QJFHH2 TuivlgWjltbV8ISWE

HKGETV (2019b). The Analysis of Tear Gas in Hong Kong: The Review of Dioxins in Tear Gas. HKGETV.

https://cdn.hkgetv.com/report/HKGETV\%20Tear\%20Gas\%20Project\%20Report\%20Dioxi n\%2020191127.pdf 
Hong Kong Free Press. (2019). November 20). Hong Kong health chief says no evidence tear gas poses public health risks. Hong Kong Free Press HKFP. https://www.hongkongfp.com/2019/11/20/hong-kong-health-chief-saysno-evidencetear-gas-poses-public-health-risks/

Rancière, J. (1991). The ignorant schoolmaster: Five lessons in intellectual emancipation (K. Ross Trans.). Stanford University Press.

Rancière, J. (1995). On the shores of politics. Verso.

Rancière, J. (1999). Dis-agreement: Politics and philosophy. University of Minnesota Press.

Rancière, J. (2003). The philosopher and his poor. Duke University Press.

Rancière, J. (2004). Who Is the Subject of the Rights of Man?. The South Atlantic Quarterly, 103(2), 297-310.

Rancière, J. (2009). A few remarks on the method of Jacques Rancière. Parallax, 15(3), 114-123. doi:10.1080/13534640902982983

Rancière, J. (2011a). The politics of aesthetics: The distribution of the sensible (G. Rockhill Trans.). Bloomsbury Academic.

Rancière, J. (2011b). The Thinking of Dissensus: Politics and Aesthetics. In P. Bowman \& R. Stamp (Eds.), Reading Rancière (pp. 1-17). Continuum. 